\title{
Reese-Ellsworth Classification IVB
}

National Cancer Institute

\section{Source}

National Cancer Institute. Reese-Ellsworth Classification IVB. NCI Thesaurus. Code C123375.

Any lesion extending anteriorly to the ora serrata. 